\title{
Synthetic routes to Cleistopholine and methylated analogues
}

\author{
A. Paul Krapcho* and Michael Ellis \\ Department of Chemistry, The University of Vermont, Burlington, VT 05405, USA \\ E-mail:pkrapcho@zoo.uvm.edu
}

(received 10 Feb 00; accepted 13 Feb 00; published on the web 21 Feb 00)

\begin{abstract}
Two synthetic pathways have been developed which lead to the natural product cleistopholine (1). One route has been adapted for the synthesis of the methylated analogues 2 and 3 . The key step involved nickel-catalyzed regiospecific coupling of benzylic zinc bromides with methyl-2bromo-4-methyl nicotinate (10) to afford benzylated pyridines followed by their subsequent transformations to the benzo[g]quinoline-5,10-diones.
\end{abstract}

Keywords: Regiospecific coupling, cleistopholine, benzylated pyridines

\section{Introduction}<smiles>[R]c1cc([R])c2c(c1)C(=O)c1nccc(C)c1C2=O</smiles>

$\mathbf{1}, \mathrm{R}=\mathrm{R}_{1}=\mathrm{H}$

2, $\mathrm{R}=\mathrm{H}, \mathrm{R}_{1}=\mathrm{CH}_{3}$

3, $\mathrm{R}=\mathrm{CH}_{3}, \mathrm{R}_{1}=\mathrm{H}$<smiles>O=C1c2ccccc2-c2nccc3ccnc1c23</smiles>

4

Cleistopholine (1) is a naturally occurring benzo[g]quinoline-5,10-dione which has been isolated from the root bark of Cleistopholis patens (Annonceae), ${ }^{1}$ the stem bark of Oncodostigma monosperma (Annonaceae), ${ }^{2}$ the trunk bark of Meiogyne virgata polyalthia (Unoneae) ${ }^{3}$ and the fruit seeds of Annona cherimolia. ${ }^{4}$ Cleistopholine (1) exhibits some antimicrobial activity ${ }^{5,6}$ but weak in vitro activity against several cancerous cell lines. ${ }^{7}$ It is also an intermediate in the synthesis of the antifungal agent sampangine (4). ${ }^{8,9,10}$

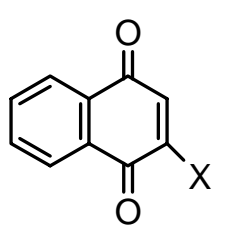

5a, $\mathrm{X}=\mathrm{Br}$

$5 \mathbf{b}, \mathrm{X}=\mathrm{H}$

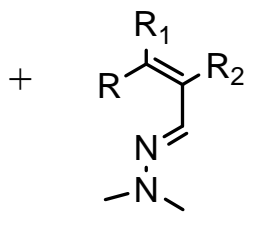

6a, $\mathrm{R}=\mathrm{R}_{2}=\mathrm{H}, \mathrm{R}_{1}=\mathrm{CH}_{3}$ 6b, $\mathrm{R}=\mathrm{R}_{2}=\mathrm{H}, \mathrm{R}_{1}=\mathrm{CH}_{2} \mathrm{CH}_{3}$ 6c, $\mathrm{R}_{1}=\mathrm{H}, \mathrm{R}=\mathrm{R}_{2}=\mathrm{CH}_{3}$<smiles>[R1]c1cnc2c(c1[R])C(=O)c1ccccc1C2=O</smiles>

7a, $\mathrm{R}=\mathrm{CH}_{2} \mathrm{CH}_{3}, \mathrm{R}_{1}=\mathrm{H}$

7b, $\mathrm{R}=\mathrm{R}_{1}=\mathrm{CH}_{3}$ 
Cleistopholine (1) has been prepared by cycloaddition of 2-bromo-1,4-naphthoquinone (5a) to azadiene $6 \mathbf{a}^{8}{ }^{8}$ This type of strategy has been utilized for the preparation of $7 \mathbf{a}$ (cycloaddition of $5 \mathbf{a}$ and $\mathbf{6 b})^{9}$ and $\mathbf{7 b}(\mathbf{5 a}$ and $\mathbf{6 c}){ }^{10}$ The cycloaddition of naphthoquinone $5 \mathbf{b}$ with azadiene $\mathbf{6 a}$ led to a dihydropyridine which on oxidation afforded $1{ }^{7}$ A multi-step, low yielding synthesis of $\mathbf{1}$ has also been developed by Koyama. ${ }^{11}$

These cycloadditions, with no substitutents on the benzenoid ring of the naphthoquinone, can yield a single regioisomeric product. The adaptation of this methodology for the preparation of benzo[g]quinoline-5,10-diones with specific substitution on the benzenoid ring present regiochemical problems as two modes of cycloaddition are possible. In addition, the synthesis of the requisite dienophilic quinones such as 6-methyl-2-bromo-1,4-naphthoquinone are difficult. ${ }^{12}$

\section{Results and Discussion}

We wish to report a synthetic procedure which leads not only to $\mathbf{1}$, but to two specifically substituted methyl analogues 2 and $\mathbf{3}$. The synthetic pathway is illustrated in Scheme 1.<smiles>[R]c1ccc(CBr)c([R])c1</smiles>

8<smiles>[R]c1ccc(C[Ga])c(CI)c1[R]</smiles><smiles>CC(=O)c1c(C)ccnc1Br</smiles>

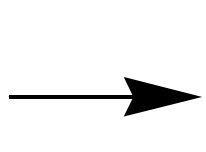

\section{R}<smiles>[R]c1cc([R])c(Cc2nccc(C)c2C)c([R])c1[R]</smiles>

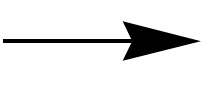<smiles>[R]c1ccc(Cc2nccc(C)c2O)c([R])c1</smiles><smiles>[R]c1ccc(Cc2nccc(C)c2C(=O)O)c([R])c1</smiles>

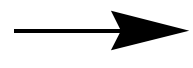<smiles>[R]c1cc([R])c2c(c1)C(=O)c1nccc(C)c1C2=O</smiles>

1, $\mathrm{R}=\mathrm{R}_{1}=\mathrm{H}$

2, $\mathrm{R}=\mathrm{H}, \mathrm{R}_{1}=\mathrm{CH}_{3}$

$3, \mathrm{R}=\mathrm{CH}_{3}, \mathrm{R}_{1}=\mathrm{H}$

14

Legend: $a, \mathrm{R}=\mathrm{R}_{1}=\mathrm{H} ; \mathrm{b}, \mathrm{R}=\mathrm{H}, \mathrm{R}_{1}=\mathrm{CH}_{3} ; \mathrm{c}, \mathrm{R}=\mathrm{CH}_{3}, \mathrm{R}_{1}=\mathrm{H}$

\section{Scheme 1}


Treatment of 8a-c with zinc dust in THF at $0{ }^{\circ} \mathrm{C}$ led to the formation of the benzylic zinc bromides 9a-c. Addition of 9a-c to a mixture of the methyl ester $\mathbf{1 0},{ }^{13}$ bis(triphenylphosphine)nickel (II) chloride and THF yielded 11a-c, respectively, in high yields. ${ }^{14,15}$ Treatment of 11a-c with lithium aluminum hydride afforded the corresponding alcohols 12a-c in nearly quantitative yields. Oxidations of the alcohols 12a-c with pyridinium chlorochromate (PCC) gave the aldehydes 13a-c in good yields.

The aldehydes 13a-c on heating with polyphosphoric acid gave the corresponding azaanthracenes 14a-c in high yields. ${ }^{15,16}$ Finally, ceric ammonium nitrate (CAN) oxidations ${ }^{17}$ of 14a-c afforded cleistopholine (1, 52\%), 2 (33\%) and 3 (40\%).<smiles>O=Cc1ccnc2c1C(=O)c1ccccc1C2=O</smiles>

15

It is of interest to note, that in the CAN oxidation of 14a with excess oxidant and long reaction times, aldehyde $\mathbf{1 5}$ could be isolated along with the desired product $\mathbf{1}$. This aldehyde was also formed on oxidation of 1 with CAN.

An alternative synthesis of $\mathbf{1}$ was accomplished by the route shown in Scheme 2.<smiles>[R]c1ccc(CC2=NCCC(C)=C2C(=O)O)c([R])c1</smiles>

11a-c

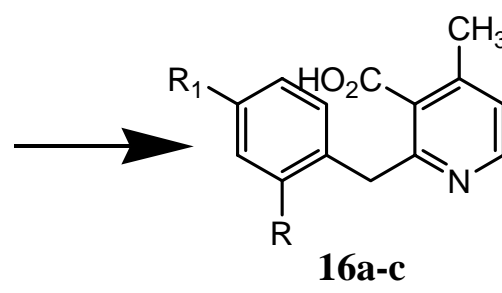

a, $\mathrm{R}=\mathrm{R}_{1}=\mathrm{H}$
b, $\mathrm{R}=\mathrm{H}_{1} \mathrm{R}_{1}=\mathrm{CH}_{3}$
c, $\mathrm{R}=\mathrm{CH}_{3}, \mathrm{R}_{1}=\mathrm{H}$

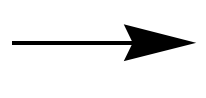<smiles>[R]c1cc([R])c2c(c1)C(=O)c1nccc(C)c1C2=O</smiles>

$1, \mathrm{R}=\mathrm{R}_{1}=\mathrm{H}$

$2, \mathrm{R}=\mathrm{H}, \mathrm{R}_{1}=\mathrm{CH}_{3}$

$3, \mathrm{R}=\mathrm{CH}_{3}, \mathrm{R}_{1}=\mathrm{H}$

\section{Scheme 2}

The sterically hindered ester of 11a was found to be quite resistant to hydrolysis on treatment with a refluxing aqueous sodium hydroxide solution. However, the conversion of 11a to 16a could be accomplished by treatment with sodium hydroxide in a $60 \%$ dioxane-water solution in a sealed tube at $125{ }^{\circ} \mathrm{C}$ for 18 hours. ${ }^{18,19}$ This acid 16a on treatment with fuming sulfuric acid led to cleistopholine $(\mathbf{1}, 60 \%)$. The esters $11 \mathbf{b}-\mathbf{c}$ could be hydrolyzed to the corresponding acids $\mathbf{1 6 b}$ c in a manner similar to that used to hydrolyze 11a. However, attempts to cyclize 11b-c to the corresponding products $\mathbf{2}$ and $\mathbf{3}$ were unsuccessful. 


\section{Conclusions}

The synthesis of cleistopholine (1) and two methyl-substituted analogues $\mathbf{2}$ and $\mathbf{3}$ have been accomplished. The synthetic pathway will prove useful in the synthesis of other substituted analogues.

\section{Experimental Section}

General Procedures. All ${ }^{1} \mathrm{H}$ and ${ }^{13} \mathrm{C}$ data were collected on a Bruker ARX-500 pulsed spectrometer. Melting points were obtained using a Thomas-Hoover capillary apparatus and are uncorrected. The benzylic bromides and zinc metal were purchased from Aldrich. The bis(tripheylphosphine)nickel (II) chloride was purchased from Lancaster of Strem and used as received. The THF was freshly distilled from potassium metal before use. Microanalysis were obtained from Robertson Microlit Laboratories, Inc., Madison, NJ.

Typical procedures are presented for the synthesis of cleistopholine (1) which were appropriately modified for the preparation of $\mathbf{2}$ and $\mathbf{3}$.

\section{4-Methylbenzo[g]quinoline-5,10-dione (Cleistopholine, 1)}

Method A (From 14a). A solution of CAN (0.41 g, $0.73 \mathrm{mmol})$ and water $(2.5 \mathrm{~mL})$ was added slowly to a solution of 14a $(0.028 \mathrm{~g}, 0.14 \mathrm{mmol})$ and acetonitrile $(5 \mathrm{~mL})$ which was kept at $0{ }^{\circ} \mathrm{C}$. The mixture was allowed to stir for $1.5 \mathrm{~h}$ and then poured into a separatory funnel, which contained ice-cold water $(10 \mathrm{~mL})$. The product was extracted into dichloromethane $(4 \mathrm{x} 10 \mathrm{~mL})$ and the combined extracts dried over magnesium sulfate. The solvent was removed to afford a yellow-brown residue which was purified by flash chromatography (silica gel, $1 \mathrm{~cm}$ x $12 \mathrm{~cm}, 2: 1$ hexane:ethyl acetate) to yield $1(0.016 \mathrm{~g}, 52 \%)$ as a yellow solid which darkened on standing in air for short periods; mp 186-190 ${ }^{\circ} \mathrm{C}$, lit. ${ }^{1} \mathrm{mp} 185-190{ }^{\circ} \mathrm{C} ;{ }^{1} \mathrm{H}$ NMR $\left(\mathrm{CDCl}_{3}\right) \delta 8.89(\mathrm{~d}, \mathrm{~J}=4.8$ $\mathrm{Hz}, 1 \mathrm{H}), 8.35(\mathrm{~m}, 1 \mathrm{H}), 8.25(\mathrm{~m}, 1 \mathrm{H}), 7.81(\mathrm{~m}, 2 \mathrm{H}), 7.49(\mathrm{~d}, \mathrm{~J}=5.1 \mathrm{~Hz}, 1 \mathrm{H}), 2.90(\mathrm{~s}, 3 \mathrm{H}):{ }^{13} \mathrm{C}$ NMR $\left(\mathrm{CDCl}_{3}\right) \delta 184.6,181.7,153.2,151.8,149.9,134.6,134.2,132.6,131.2,129.1,127.4$, 127.2, 22.8 .

Method B (from Acid 16a). Fuming sulfuric acid ( $2 \mathrm{~mL}, 20 \%$ free $\mathrm{SO}_{3}$ ) was slowly added to 16a $(0.076 \mathrm{~g}, 0.33 \mathrm{mmol})$ at room temperature. The mixture was placed in an oil bath which was preheated to $80{ }^{\circ} \mathrm{C}$ and held at this temperature for $45 \mathrm{~min}$. The cooled mixture was poured over ice $(10 \mathrm{~g})$ and the mixture was basified to $\mathrm{pH}=8$ by the addition of solid sodium bicarbonate. The product was extracted into dichloromethane $(3 \times 20 \mathrm{~mL})$, the extracts dried over magnesium sulfate and the solvent removed by rotary evaporation to yield $1(0.044 \mathrm{~g}, 60 \%)$.

4,7-Dimethylbenzo[g]quinoline-5,10-dione (2). Prepared from 14b by modification of Method A to yield $2(33 \%)$ as a yellow solid which quickly darkened on standing in air; mp $210-212{ }^{\circ} \mathrm{C}$; ${ }^{1} \mathrm{H}$ NMR $\left(\mathrm{CDCl}_{3}\right) \delta 8.89(\mathrm{~d}, \mathrm{~J}=4.8 \mathrm{~Hz}, 1 \mathrm{H}), 8.26(\mathrm{~d}, \mathrm{~J}=7.9 \mathrm{~Hz}, 1 \mathrm{H}), 8.06(\mathrm{~s}, 1 \mathrm{H}), 7.61(\mathrm{~d}, \mathrm{~J}=$ $7.9 \mathrm{~Hz}, 1 \mathrm{H}), 7.48(\mathrm{~d}, \mathrm{~J}=4.7 \mathrm{~Hz}, 1 \mathrm{H}), 2.91(\mathrm{~s}, 3 \mathrm{H}), 2.55$ (s, 3H). 
4,9-Dimethylbenzo[g]quinoline-5,10-dione (3). Prepared from 14c by modification of Method A to yield $3(40 \%)$ as a yellow solid which darkened on standing in air; mp $182-184{ }^{\circ} \mathrm{C} ;{ }^{1} \mathrm{H}$ $\operatorname{NMR}\left(\mathrm{CDCl}_{3}\right) \delta 8.87(\mathrm{~d}, \mathrm{~J}=4.7 \mathrm{~Hz}, 1 \mathrm{H}), 8.18(\mathrm{~d}, \mathrm{~J}=7.4 \mathrm{~Hz}, 1 \mathrm{H}), 7.67-7.59(\mathrm{~m}, 2 \mathrm{H}), 7.45(\mathrm{~d}, \mathrm{~J}$ $=4.7 \mathrm{~Hz}, 1 \mathrm{H}), 2.89(\mathrm{~s}, 3 \mathrm{H}), 2.87(\mathrm{~s}, 3 \mathrm{H})$.

\section{Methyl 2-benzyl-4-methyl nicotinate (11a)}

A solution of benzyl bromide (8a, $3.2 \mathrm{~g}, 18.7 \mathrm{mmol})$ in THF $(30 \mathrm{~mL})$ was added via syringe to a stirring suspension of zinc dust $(1.72 \mathrm{~g}, 26.3 \mathrm{mmol})$ and THF $(40 \mathrm{~mL})$ held at $0{ }^{\circ} \mathrm{C}$. The mixture was allowed to stir for $3 \mathrm{~h}$, the residual zinc was allowed to settle and the benzylic zinc bromide solution was added via cannulation under nitrogen pressure to a mixture of bis(triphenylphosphine)nickel (II) chloride (3.1 g, $4.7 \mathrm{mmol}), 10$ (2.6 g, $10.7 \mathrm{mmol})$ and THF ( $110 \mathrm{~mL}$ ). The resultant dark brown mixture was stirred at room temperature for $42 \mathrm{~h}$. The mixture was quenched by the addition of $10 \%$ aqueous ammonium chloride $(75 \mathrm{~mL})$ and allowed to stir for $30 \mathrm{~min}$. The mixture was extracted with ethyl acetate $(150 \mathrm{~mL})$, washed with brine $(3 \mathrm{x}$ $75 \mathrm{~mL}$ ) and dried over magnesium sulfate. The solvent was removed by rotary evaporation to yield a brown liquid which was purified by flash chromatography (silica gel, $10 \mathrm{~cm}$ x $18 \mathrm{~cm}, 3: 1$ hexane: ethyl acetate) to afford 11a $(2.14 \mathrm{~g}, 86 \%)$ as a clear slightly yellow oil; ${ }^{1} \mathrm{H}$ NMR $\left(\mathrm{CDCl}_{3}\right) \delta 8.42(\mathrm{~d}, \mathrm{~J}=5.3 \mathrm{~Hz}, 1 \mathrm{H}), 7.16(\mathrm{~m}, 5 \mathrm{H}), 7.07(\mathrm{~d}, \mathrm{~J}=5.3 \mathrm{~Hz}, 1 \mathrm{H}), 4.25(\mathrm{~s}, 2 \mathrm{H}), 3.73$ (s, $3 \mathrm{H}), 2.30$ (s, 3H). Anal. Calcd. for $\mathrm{C}_{15} \mathrm{H}_{15} \mathrm{NO}_{2}$ : C, 74.67; H, 6.27; N, 5.81. Found: C, 74.28; H, $6.16 ; \mathrm{N}, 5.43$.

Methyl 2-(4-methylbenzyl)-4-methyl nicotinate (11b). Modification of the procedure leading to $\mathbf{1 1 a}$ commencing with $\mathbf{8 b}$ led to $\mathbf{1 1 b}(82 \%)$ as a clear colorless oil; ${ }^{1} \mathrm{H} \mathrm{NMR}\left(\mathrm{CDCl}_{3}\right) \delta 8.45$ $(\mathrm{d}, \mathrm{J}=5.1 \mathrm{~Hz}, 1 \mathrm{H}), 7.09(\mathrm{~m}, 4 \mathrm{H}), 7.03(\mathrm{~d}, \mathrm{~J}=5.1 \mathrm{~Hz}, 1 \mathrm{H}), 4.18$ (s, 2H), 3.81 (s, 3H), 2.31 (s, $3 \mathrm{H}), 2.29$ (s, 3H). Anal. Calcd. for $\mathrm{C}_{16} \mathrm{H}_{17} \mathrm{NO}_{2}$ : C, 75.27; H, 6.71; N, 5.49. Found: C, 75.31; H, $6.94 ; \mathrm{N}, 5.61$.

Methyl 2-(2-methylbenzyl)-4-methyl nicotinate (11c). Modification of the procedure leading to 11a starting with $8 \mathrm{c}$ led to $11 \mathrm{c}(82 \%)$ as a clear colorless oil; ${ }^{1} \mathrm{H}$ NMR $\left(\mathrm{CDCl}_{3}\right) \delta 8.45(\mathrm{~d}, \mathrm{~J}=$ $5.1 \mathrm{~Hz}, 1 \mathrm{H}), 7.12(\mathrm{~m}, 3 \mathrm{H}), 7.06(\mathrm{~d}, \mathrm{~J}=5.1 \mathrm{~Hz}, 1 \mathrm{H}), 6.95(\mathrm{~m}, 1 \mathrm{H}), 4.25(\mathrm{~s}, 2 \mathrm{H}), 3.70(\mathrm{~s}, 3 \mathrm{H}), 2.33$ $(\mathrm{s}, 3 \mathrm{H}), 2.25$ (s, 3H). Anal. Calcd. for $\mathrm{C}_{16} \mathrm{H}_{17} \mathrm{NO}_{2}$ : C, 75.27; H, 6.71; N, 5.49. Found: C, 75.42; $\mathrm{H}, 6.65 ; \mathrm{N}, 5.43$.

\section{2-Benzyl-3-hydroxymethyl-4-methyl pyridine (12a)}

A solution of 11a $(0.125 \mathrm{~g}, 0.53 \mathrm{mmol})$ in ether $(6 \mathrm{~mL})$ was added to a suspension of lithium aluminum hydride $(0.06 \mathrm{~g}, 1.6 \mathrm{mmol})$ in ether $(5 \mathrm{~mL})$ at $0{ }^{\circ} \mathrm{C}$. After $1 \mathrm{~h}$ the mixture was treated with cold water $(5 \mathrm{~mL})$ and the precipitate was removed by filtration. The filtrate was extracted with dichloromethane $(3 \times 15 \mathrm{~mL})$, the combined extracts were dried over magnesium sulfate and concentrated by rotary evaporation to yield a yellow oil which was purified by flash chromatography (silica gel, $2 \mathrm{~cm}$ x $16 \mathrm{~cm}, 1: 1$ hexane:ethyl acetate) to yield 12a $(0.51 \mathrm{~g}, 96 \%)$ as a colorless oil; ${ }^{1} \mathrm{H}$ NMR $\left(\mathrm{CDCl}_{3}\right) \delta 8.4(\mathrm{~d}, \mathrm{~J}=5.2 \mathrm{~Hz}, 1 \mathrm{H}), 7.32(\mathrm{~m}, 5 \mathrm{H}), 7.16(\mathrm{~d}, \mathrm{~J}=5.2 \mathrm{~Hz}$, $1 \mathrm{H}), 4.77$ (s, 2H), 4.43 (s, 2H), 2.51 (s, 3H). Anal. Calcd. for $\mathrm{C}_{14} \mathrm{H}_{15} \mathrm{NO}_{2}$ : C, 77.74; H, 6.93; N, 
6.46. Found: C, 77.56; H, 7.22; N, 6.42 .

2-(4-Methylbenzyl)-3-hydroxymethyl-4-methyl pyridine (12b). Modification of the procedure leading to $\mathbf{1 2 a}$ commencing from $\mathbf{1 1 b}$ led to $\mathbf{1 2 b}(98 \%)$ as a white solid; $\mathrm{mp} 120-122{ }^{\circ} \mathrm{C} ;{ }^{1} \mathrm{H}$ $\operatorname{NMR}\left(\mathrm{CDCl}_{3}\right) \delta 8.38(\mathrm{~d}, \mathrm{~J}=5.0 \mathrm{~Hz}, 1 \mathrm{H}), 7.09(\mathrm{~m}, 4 \mathrm{H}), 7.03(\mathrm{~d}, \mathrm{~J}=5.0 \mathrm{~Hz}, 1 \mathrm{H}), 4.69(\mathrm{~d}, \mathrm{~J}=4.4$ $\mathrm{Hz}, 2 \mathrm{H}), 4.29$ (s, 2H), 2.41 (s, 3H), 2.29 (s, 3H). Anal. Calcd. for $\mathrm{C}_{15} \mathrm{H}_{17} \mathrm{NO}$ : C, 79.26; H, 7.54; N, 6.16. Found: C, 79.05; H, 7.45; N, 5.99.

2-(2-Methylbenzyl)-3-hydroxymethyl-4-methyl pyridine (12c). Modification of the procedure leading to 12a commencing from 11c led to $12 \mathrm{c}(97 \%)$ as a clear colorless oil; ${ }^{1} \mathrm{H} \mathrm{NMR}\left(\mathrm{CDCl}_{3}\right)$ $\delta 8.37(\mathrm{~d}, \mathrm{~J}=5.1 \mathrm{~Hz}, 1 \mathrm{H}), 7.17(\mathrm{~d}, \mathrm{~J}=7.4 \mathrm{~Hz}, 1 \mathrm{H}), 7.11(\mathrm{~m}, 1 \mathrm{H}), 7.04(\mathrm{~d}, \mathrm{~J}=5.2 \mathrm{~Hz}, 1 \mathrm{H}), 6.75$ $(\mathrm{d}, \mathrm{J}=7.4 \mathrm{~Hz}, 1 \mathrm{H}), 4.60(\mathrm{~s}, 2 \mathrm{H}), 4.28(\mathrm{~s}, 2 \mathrm{H}), 2.43(\mathrm{~s}, 3 \mathrm{H}), 2.34(\mathrm{~s}, 3 \mathrm{H})$. Anal. Calcd. for $\mathrm{C}_{15} \mathrm{H}_{17} \mathrm{NO}$ : C, 79.26; H, 7.54; N, 6.16. Found: C, 79.21; H, 7.34; N, 6.02.

\section{2-Benzyl-4-methyl-pyridine-3-carboxaldehyde (13a)}

A solution of 12a $(0.25 \mathrm{~g}, 1.17 \mathrm{mmol})$ in chloroform $(2 \mathrm{~mL})$ was added to a suspension of PCC $(0.38 \mathrm{~g}, 1.77 \mathrm{mmol})$ in chloroform $(2 \mathrm{~mL})$ which was being stirred at room temperature. The brownish mixture was stirred for $40 \mathrm{~min}$. and ether $(15 \mathrm{~mL})$ was added. The decanted solution was concentrated and the crude product purified by flash chromatography (silica gel, $1.5 \mathrm{x} 14$ $\mathrm{cm}$, hexane: ethyl acetate $3: 1)$ to yield 13a $(0.197 \mathrm{~g}, 80 \%)$ as a colorless oil which quickly darkened on standing in the air; ${ }^{1} \mathrm{H} \operatorname{NMR}\left(\mathrm{CDCl}_{3}\right) \delta 10.51(\mathrm{~s}, 1 \mathrm{H}), 8.50(\mathrm{~d}, \mathrm{~J}=5.1 \mathrm{~Hz}, 1 \mathrm{H}), 7.17$ (m, 5H), 7.09 (d, J = 5.2 Hz, 1H), 4.50 (s, 2H), 2.54 (s, 3H).

4-Methyl-2-(4-methylbenzyl)-pyrdine-3-carboxylate (13b). Adaptation of the procedure for 13a commencing from 12b led to $\mathbf{1 3 b}(60 \%)$ as a light yellow oil which quickly darkened on standing in air; ${ }^{1} \mathrm{H}$ NMR $\left(\mathrm{CDCl}_{3}\right) \delta 10.59(\mathrm{~s}, 1 \mathrm{H}), 8.55(\mathrm{~d}, \mathrm{~J}=5.1 \mathrm{~Hz}, 1 \mathrm{H}), 7.08(\mathrm{~m}, 5 \mathrm{H}), 4.48(\mathrm{~s}$, $2 \mathrm{H}), 2.58(\mathrm{~s}, 3 \mathrm{H}), 2.28(\mathrm{~s}, 3 \mathrm{H})$.

4-Methyl-2-(2-methylbenzyl)-pyridine-3-carboxaldehyde (13c). Modification of the procedure for 13a commencing with 12c led to 13c $(68 \%)$ which quickly darkened on standing in air; ${ }^{1} \mathrm{H} \mathrm{NMR}\left(\mathrm{CDCl}_{3}\right) \delta 10.47(\mathrm{~s}, 1 \mathrm{H}) ; 8.55(\mathrm{~d}, \mathrm{~J}=5.0 \mathrm{Hx}, 1 \mathrm{H}), 7.17(\mathrm{~d}, \mathrm{~J}=7.4 \mathrm{~Hz}, 1 \mathrm{H}), 7.12$ (m, 2H), $7.05(\mathrm{~m}, 1 \mathrm{H}), 6.74(\mathrm{~d}, \mathrm{~J}=7.4 \mathrm{~Hz}, 1 \mathrm{H}), 4.48(\mathrm{~s}, 2 \mathrm{H}), 2.62$ (s, 3H), 2.34 (s, 3H).

\section{4-Methylbenzo[g]quinoline (14a)}

A mixture of 13a $(0.19 \mathrm{~g}, 0.89 \mathrm{mmol})$ and polyphosphoric acid $(6.7 \mathrm{~g})$ was heated at $140{ }^{\circ} \mathrm{C}$ in an oil bath under a nitrogen atmosphere. After being held at this temperature for $1.5 \mathrm{~h}$, the viscous mixture was cooled and added to ice-water $(15 \mathrm{~mL})$. The mixture was basified to $\mathrm{pH}=$ 8.5 with a $10 M$ sodium hydroxide solution and the product extracted into dichloromethane $(3 \mathrm{x}$ $20 \mathrm{~mL}$ ). The combined extracts were dried over magnesium sulfate and the solvent removed by rotary evaporation to yield brown oil, which solidified on standing overnight. This material was purified by flash chromatography (silica gel, $1.5 \mathrm{~cm} \mathrm{x} 22 \mathrm{~cm}$, dichloromethane:methanol 95:5) to afford 14a $(0.0134 \mathrm{~g}, 77 \%)$ as a yellow solid; mp 105-107 ${ }^{\circ} \mathrm{C} ;{ }^{1} \mathrm{H} \mathrm{NMR}\left(\mathrm{CDCl}_{3}\right) \delta 8.85(\mathrm{~d}, \mathrm{~J}=$ $4.1 \mathrm{~Hz}, 1 \mathrm{H}), 8.69(\mathrm{~s}, 1 \mathrm{H}), 8.52(\mathrm{~s}, 1 \mathrm{H}), 8.07(\mathrm{~m}, 2 \mathrm{H}), 7.52(\mathrm{~m}, 2 \mathrm{H}), 7.19(\mathrm{~d}, \mathrm{~J}=4.2 \mathrm{~Hz}, 1 \mathrm{H}), 2.81$ 
(s, 3H). Anal. Calcd. for $\mathrm{C}_{14} \mathrm{H}_{11} \mathrm{~N}$ : C, 83.16; H, 5.94; N, 6.93. Found: C, 83.33; H, 6.22; N, 6.65. 4,7-Dimethylbenzo[g]quinoline (14b). Modification of the preparation of $14 a$ starting from $13 \mathbf{b}$ led to $14 \mathbf{b}(90 \%)$ as a yellow solid; $\mathrm{mp} 127-130{ }^{\circ} \mathrm{C} ;{ }^{1} \mathrm{H} \mathrm{NMR}\left(\mathrm{CDCl}_{3}\right) \delta 8.82(\mathrm{~d}, \mathrm{~J}=4.1 \mathrm{~Hz}, 1 \mathrm{H})$, $8.64(\mathrm{~s}, 1 \mathrm{H}), 8.42$ (s, 1H), 7.99 (d, J = 8.7 Hz, 1H), 7.81 (s, 1H), 7.38 (d, J = 8.7 Hz, 1H), 7.18 (d, $\mathrm{J}=4.1 \mathrm{~Hz}, 1 \mathrm{H}), 2.18(\mathrm{~s}, 3 \mathrm{H}), 2.57$ (s, 3H). Anal. Calcd. for $\mathrm{C}_{15} \mathrm{H}_{13} \mathrm{~N}$ : C, 86.92; H, 6.32; N, 6.67. Found: C, 86.80; H, 6.38; N, 6.34.

4,9-Dimethylbenzo[g]quinoline (14c). Modification of the procedure for 14a starting from 13c led to $14 \mathrm{c}(72 \%)$ as a yellow solid; $\mathrm{mp} 129-131{ }^{\circ} \mathrm{C} ;{ }^{1} \mathrm{H} \mathrm{NMR}\left(\mathrm{CDCl}_{3}\right) \delta 8.83(\mathrm{~d}, \mathrm{~J}=4.1 \mathrm{~Hz}, 1 \mathrm{H})$, $8.81(\mathrm{~s}, 1 \mathrm{H}), 8.47(\mathrm{~s}, 1 \mathrm{H}), 7.88(\mathrm{~d}, \mathrm{~J}=8.4 \mathrm{~Hz}, 1 \mathrm{H}), 7.77(\mathrm{~m} 2 \mathrm{H}), 7.17(\mathrm{~d}, \mathrm{~J}=3.7 \mathrm{~Hz}, 1 \mathrm{H}), 2.82(\mathrm{~s}$, $3 \mathrm{H}), 2.78(\mathrm{~s}, 3 \mathrm{H})$. Anal. Calcd. for $\mathrm{C}_{15} \mathrm{H}_{13} \mathrm{~N}$ : C, 86.92; H, 6.32; N, 6.67. Found: C, 86.82; H, $6.40 ; \mathrm{N}, 6.60$.

Benzo[g]quinoline-5,10-dione-4-carboxaldehyde (15). A solution of THF: water (75:25) and CAN (1.2 g, $2.2 \mathrm{mmol})$ was added to cleistopholine $(1,0.052 \mathrm{~g}, 0.23 \mathrm{mmol})$. The orange mixture was stirred for $24 \mathrm{~h}$ at room temperature, poured into water $(40 \mathrm{~mL})$ and extracted into dichloromethane $(3 \times 40 \mathrm{~mL})$. The combined extracts were dried over magnesium sulfate and the solvent removed by rotary evaporation to afford a bright yellow solid. This was purified by flash chromatography (silica gel, $1.5 \mathrm{~cm}$ x $22 \mathrm{~cm}$, chloroform:methanol 99:1) to yield $15(0.0004 \mathrm{~g}$, $7 \%)$ as a yellow solid which quickly darkened on standing; mp $211-215{ }^{\circ} \mathrm{C} ;{ }^{1} \mathrm{H}$ NMR $\left(\mathrm{CDCl}_{3}\right) \delta$ 10.88 (s, 1H), 9.26 (d, J = 4.66 Hz, 1H), $8.43(\mathrm{~m}, 2 \mathrm{H}), 8.32(\mathrm{~m}, 1 \mathrm{H}), 7.90(\mathrm{~m}, 2 \mathrm{H}), 7.87(\mathrm{~d}, \mathrm{~J}=$ $4.67 \mathrm{~Hz}, 1 \mathrm{H}) .{ }^{13} \mathrm{C} \mathrm{NMR}\left(\mathrm{CDCl}_{3}\right) \delta 191.4,184.2,180.7,155.8,149.8,145.7,135.4,135.0,133.0$, $132.7,128.8,128.2,127.6,125.4$.

2-Benzyl-4-methyl nicotinic acid (16a). A mixture of 11a (0.57 g, $2.35 \mathrm{mmol})$, sodium hydroxide $(0.38 \mathrm{~g}, 9.45 \mathrm{mmol})$ and a $60 \%$ mixture of dioxane in water $(100 \mathrm{~mL})$ was heated in a sealed tube held at $125{ }^{\circ} \mathrm{C}$ for $18 \mathrm{~h}$. The cooled mixture was concentrated to about $1 / 3$ volume by rotary evaporation, water $(20 \mathrm{ml})$ was added and the volume was again reduced to $1 / 3$ volume. The resultant brown liquid was acidified with concentrated hydrochloric acid to $p H 5$. The precipitated acid was collected by filtration and allowed to air dry overnight to yield 16a $(0.403$ g, 72\%) as a white solid; mp 197-199 ${ }^{\circ} \mathrm{C} ;{ }^{1} \mathrm{H}$ NMR $\left(\mathrm{CDCl}_{3}\right) \delta 8.39(\mathrm{~d}, \mathrm{~J}=4.96 \mathrm{~Hz}, 1 \mathrm{H}), 7.18(\mathrm{~m}$, $6 \mathrm{H}), 4.10(\mathrm{~s}, 2 \mathrm{H}), 2.30(\mathrm{~s}, 3 \mathrm{H})$. Anal. Calcd. for $\mathrm{C}_{14} \mathrm{H}_{13} \mathrm{NO}_{3}$ : C, 73.99; H, 5.77; N, 6.16. Found: C, 73.87; H, 6.02; N, 6.07.

\section{References}

1. Waterman, P. G.; Muhammad, I., Phytochemistry 1985, 24, 523.

2. Bou-Abdullah, E.; Jossang, A.; Tadic, D.; Leboeuf, M, Cave, A., J. Nat. Prod. 1989, 52, 273.

3. Tadic, D.; Cassels, B. K.; Leboeuf, M.; Cave, M., Phytochemistry 1987, 26, 537. 
4. Rios, J. L.; Cortes, D.; Valverde, S., Planta Med. 1989, 55, 321.

5. Koyama, J.; Tagahara, K.; Konoshima, T.; Kozuka, M.; Yano, Y.; Taniguchi, M., Chem. Exp. 1990, 5, 557.

6. Bracher, F., Arch. Pharm. (Weinheim) 1994, 327, 371.

7. Lee, H.; Hong, S.-S.; Choi, J.-Y.; Cho, J.; Kim, Y.-H., Arch. Pharm. Res. 1998, 21,73.

8. Bracher, F., Liebigs Ann. Chem. 1989, 87.

9. Peterson, J. R.; Zjawiony, J. K.; Liu, S.; Hufford, C. D.; Clark, A. M.; Rogers, R. D., J. Med. Chem. 1992, 35, 4069.

10. Zjawiony, J. K.; Srivastava, A. R.; Hufford, C. D.; Clark, A. M., Heterocycles 1994, 39, 779.

11. Koyama, J.; Okatani, T.; Tagahara, K., Heterocycles 1989, 29, 1649.

12. Boisvert, L.; Brassard, P., J. Org. Chem. 1988, 53, 4052.

13. Baldwin, J. J.; Raab, A. W.; Ponticello, G. S., J. Org. Chem. 1978, 43, 2529.

14. Krapcho, A. P.; Gallagher, C. E.; Hammach, A.; Ellis, M.; Menta, E.; Oliva, A., J. Heterocyclic Chem. 1997, 34, 27.

15. Krapcho, A. P.; Gilmor, T. P., J. Heterocyclic Chem. 1999, 36, 445.

16. Bradsher, C. K., Chem. Rev. 1987, 87, 1277.

17. Periasamy, M.; Bhatt, M. V., Synthesis 1977, 330.

18. Bender, M. L.; Dewey, R. S., J. Am. Chem. Soc. 1956, 78, 317.

19. Newman, M. S., J. Am. Chem. Soc. 1941, 63, 2341. 